\title{
PERANCANGAN DAN IMPLEMENTASI PROTOTYPE KONTROL PERALATAN ELEKTRONIK BERBASIS INTERNET OF THINGS MENGGUNAKAN NODEMCU
}

\author{
Fahrul Ilhami' ${ }^{1,}$ Petrus Sokibi $^{2}$, Amroni $^{3}$ \\ Sekolah Tinggi Manajemen Informatika dan Komputer CIC Cirebon Jawa Barat Indonesia \\ Jl.Kesambi 202, Kota Cirebon, Jawa Barat.Tlp : (0231)220250. \\ E-mail : fahrulilhami@gmail.com¹, petrus.sokibi@cic.ac.id ${ }^{2}$, amroni@cic.ac.id ${ }^{3}$
}

\begin{abstract}
Abstrak
Era modern sekarang banyak perkembangan teknologi yang semakin membantu memudahkan sistem kontrol peralatan elektronik rumah tangga berbasis Internet of Things (IoT) dibangun dengan pertimbangan aspek kenyamanan penghuni rumah. Bagian-bagian yang dikontrol adalah perangkat elektronik seperti lampu, air, kipas dan perangkat elektronik lainnya. Saat ini kontrol dengan mikrokontroler masih dalam proses pengembangan, salah satu tujuan pengembangannya adalah untuk meningkatkan utilitas serta penyederhanaan media maupun komponen elektronik yang digunakan supaya terjangkau oleh banyak kalangan masyarakat. Berbagai penelitian dilakukan dengan secara yang di fokuskan pada pengendalian alat elektronik dengan peralatan dan kontrol yang dibuat secara berbeda-beda. Fitur efektif yang dapat memudahkan manusia dalam kesehariannya. Ketika penghuni rumah pergi jauh meninggalkan rumah dengan rentan waktu yang lama, pengontrolan peralatan elektronik tidak bisa dilakukan, terkecuali dikendalikan secara manual.Dengan tersedianya fasilitas internet dapat mengintegrasikan sistem pengontrolan peralatan elektronik secara IoT dengan modul NodeMCU. Sistem pengontrolan peralatan elektronik berbasis IoT ini dapat berjalan pada platform android minimal jelly bean dan pada windows minimal OS windows 7. Perangkat keras dan perangkat lunak pada sistem ini dapat dijalankan sesuai dengan perancangan yang dilakukan sebelumnya. Hasil dari penelitian ini berupa pembuatan prototype penerapan pengontrolan peralatan elektronik menggunakan MQTT Dash dan webserver IO.adafruit.
\end{abstract}

Kata kunci:Internet of Things (IoT), mikrokontroler, NodeMCU, relay channel, power supply, Mqtt Dash, web sever, Prototype.

\begin{abstract}
The modern era is now a lot of technological developments that increasingly help facilitate the control system of electronic devices based on the Internet of Things (IoT) was built with consideration of aspects of the comfort of residents of the house. The parts controlled are electronic devices such as lights, water, fans and other electronic devices. At present the control with a microcontroller is still in the process of development, one of the goals of its development is to improve the utility and simplification of the media and electronic components used so that it is affordable by many people. Various studies have been carried out with a focus on controlling electronic devices with equipment and controls that are made differently. Effective features that can facilitate humans in their daily lives. When the occupants of the house go far away from the house with a long time vulnerable, controlling electronic equipment can not be done, unless manually controlled. With the availability of internet facilities can integrate the electronic equipment control system IoT with the NodeMCU module. This IoT-based electronic equipment control system can run on a minimum jelly bean android platform and on a minimum Windows OS windows 7. Hardware and software on this system can be run in accordance with the design done previously. The results of this study are in the form of making prototypes of the application of electronic equipment control using MQTT Dash and IO.adafruit web server.
\end{abstract}

Keywords: Internet of Things (IoT), microcontrollers, NodeMCU, relay channel, power supply, Mqtt Dash, web sever, Prototype. 


\section{PENDAHULUAN}

Perkembangan teknologi saat ini sudah berkembang pesat dan kemampuan teknologi telah menjawab berbagai tantangan manusia untuk saling berinteraksi secara real time dimana batas antar jarak, waktu dan ruang bukanlah penghalang bagi keinginan manusia untuk saling berkomunikasi. Era digital telah merambah ke segala bidang, sehingga hampir tidak ada celah dalam kehidupan manusia yang tidak berhubungan dengan teknologi digital. Pada dasarnya sebuah teknologi sangatlah berguna untuk segala aktifitas yang akan dikerjakan bahkan sekarang dikembangkan untuk mempermudah manusia untuk mengontrol sesuatu. Salah satu contohnya adalah untuk mengontrol sebuah peralatan elektronik yang ada dirumah.

Rumah pintar atau smart home merupakan bagian dari inovasi Internet of Things (IoT), dimana semua benda atau perabotan sehari-hari yang akrab dengan kehidupan masyarakat dipintarkan karena integrasi teknologi dalam bentuk chip yang serba bisa. Smart home hadir untuk memudahkan para penghuni rumah dalam mengatur segala hal yang berhubungan dengan kenyamanan diri sebagai penghuni rumah, mulai dari soal keamanan hingga soal mengakses perabotan yang dibuat lebih interaktif dan bisa dikontrol melalui satu alat. Smart Home erat kaitannya dengan kecerdasan buatan yang digunakan untuk meningkatkan faktor kenyamanan keamanan dan penghematan energi dalam suatu rumah. Berbagai peralatan digunakan manusia dalam kehidupan sehari-hari untuk berbagai keperluan, seperti penerangan, peralatan dapur, hingga sistem keamanan yang serba otomatis.

Meskipun demikian, terdapat beberapa masalah yang timbul akibat penggunaan peralatan listrik tersebut, salah satunya yaitu adalah pemborosan listrik ketika seseorang lupa mematikan peralatan listrik ketika meninggalkan rumah, yang berdampak pada pemborosan energi listrik dan membengkaknya biaya listrik yang harus dikeluarkan. Selain itu kelalaian dalam mengontrol peralatan listrik yang ada dapat berakibat pada terjadinya bencana seperti kebakaran karena lupa mematikan peralatan elektronik sebelum meninggalkan rumah.

Untuk mengatasi permasalahan tersebut, perlu diciptakan suatu sistem yang dapat memudahkan pengguna dalam mengontrol perangkat elektronikBerdasarkan permasalahan yang timbul dalam pengontrolan peralatan elektronik secara manual, maka penulis tertarik dengan mengangkat judul "Perancangan dan Implementasi PrototypeKontrol Peralatan Elektronik Berbasis Internet Of Things MenggunakanNodemcu”.

\subsection{Identifikasi Masalah}

Identifikasi masalah dari penelitian ini adalah :

1. Bagaimana membuat pengontrolan peralatan elektronik melalui penerapan teknologi Internet of Things?

2. Bagaimana penerapan Internet of Things untuk mengontrol peralatan elektronik yang ada dirumah?

3. Bagaimana membuat sistem pengontrol alat elektronik rumah yang dapat dikontrol dari jarak jauh dengan web server io.Adafruit?

4. Bagaimana membuat sistem pengontrol alat elektronik rumah yang dapat dikontrol dari jarak jauh dengan android?

5. Bagaimana pengaplikasian modul NodeMCU sebagai perangkat utama dalam penerapan Internet of Things?

\subsection{Batasan masalah}

Batasan masalah dari penelitian ini adalah :

1. Mikrokontroler yang digunakan adalah jenis NodeMCU untuk kontrol peralatan elektronik.

2. Bahasa pemrograman mikrokontroler NodeMCU menggunakan bahasa $\mathrm{C}$.

3. Informasi pengontrolan perangkat elektronik dengan menggunakan webserver Adafruit dan android berupa status on/off terhadap peralatan elektronik.

4. Peralatan elektronik yang akan diuji coba yaitu lampu, kipas dan dvd. 


\subsection{Tujuan}

Tujuan dari penelitian ini adalah :

1. Dapat mengimplementasikan konsep pengontrolan alat-alat elektronik secara Internet of Things (IoT) dengan NodeMCU.

2. Merancang dan membuat prototype sistem kontrol peralatan listrik secara jarak jauh dengan menggunakan mikrokontroler NodeMCU dengan kontrol web server io.adfruit dan aplikasi android MQTT Dash.

3. Dapat mempermudah pengguna dalam mengendalikan peralatan elektronik dimanapun dan kapanpun melalui internet dengan web server dan android.

\section{STUDI LITERATUR}

\subsection{Prototype}

Suatu prototype adalah bentuk dasar atau model awal dari suatu sistem atau bagian dari suatu sistem.Setelah dioperasikan, prototype ditingkatkan terus sesuai dengan kebutuhan pemakai sistem yang juga meningkat. (HM Jogiyanto, 2003).

Menurut Jogiyanto prototyping adalah proses pengembangan suatu prototype secara cepat untuk digunakan terlebih dahulu dan ditingkatkan terus menerus sampai didapatkan sistem yang utuh. Proses membangun sistem ini yaitu dengan membuat prototype atau model awal, mencobanya, meningkatkannya dan mencobanya lagi dan meningkatkannya dan seterusnya sampai didapatkan sistem yang lengkap disebut dengan proses iteratif (iterative process) dari pengembangan sistem.

Tahapan-tahapan yang dilakukan didalam pengembangan sistem menggunakan metode prototype adalah sebagai berikut ini.

1. Identifikasi kebutuhan pemakai yang paling mendasar.

Pembuat sistem dapat mewancarai pemakai sistem tentang kebutuhan pemakai sistem yang paling minimal terlebih dahulu. Proses ini sama dengan proses analisis di pengembangan sistem SDLC.

2. Membangun prototype

Prototype dibangun oleh pembuat sistem dengan cepat.Hal ini dimungkinkan karena pembuat sistem hanya membangun bagian yang paling mendasar dulu dari keseluruhan sistem yang paling dibutuhkan terlebih dahulu oleh pemakai sistem. Hal lainnya yang memungkinkan pembuat sistem membangun prototype dengan cepat adalah dengan menggunakan alat-alat bantu generasi terbaru seperti misalnya DBMS dan CASE.

3. Menggunakan prototype

Pemakai sistem dianjurkan untuk menggunakan prototype sehingga dapat menilai kekurangan-kekurangan dari prototype sehingga dapat memberikan masukan-masukan kepada pembuat sistem.

4. Merevisi dan meningkatkan prototype

Pembuat sistem memperbaiki prototype berdasarkan keinginan dari pemakai sistem atau berdasarkan pengalamannya untuk membuat sistem sejenis yang baik. Jika prototype belum lengkap, maka proses iterasi diulangi lagi mulai dari nomor 3.

5. Jika prototype lengkap menjadi sistem yang dikehendaki, proses iterasi dihentikan.

Kelima tahapan didalam mengembangkan sistem dengan metode prototyping dapat dilihat pada gambar berikut ini. 


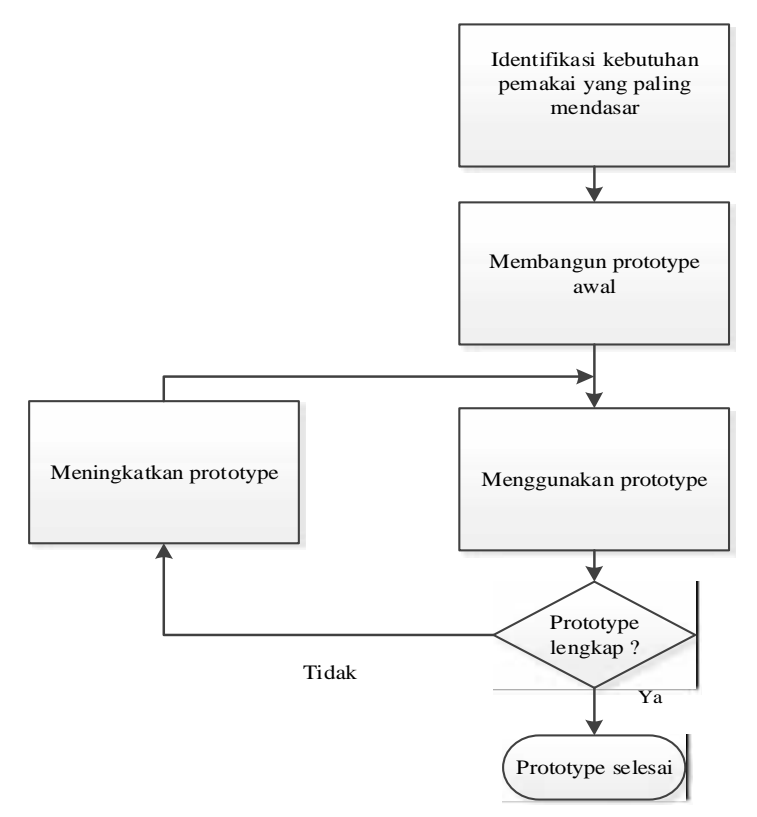

Gambar 1.Arduino Mainboard Berbasis Atmega328 dengan Boot-loader

\subsection{Internet Of Things (IoT)}

Internet of things (IoT) adalah sebuah konsep dimana perangkat perangkat elektronik nantinya akan memiliki kemampuan untuk saling berkomunikasi dengan sendirinya, saling menerima dan mengirimkan data melalui koneksi jaringan. Penerapan IoT menjadikan aktivitas dalam berbagai bidang dapat saling terhubung melalui Internet, serta menjadi lebih mudah dan efisien (Iman Hedi Santoso, 2016).Istilah IoT pertama kali diusulkan oleh Kevin Ashton dalam presentasinya di Procter \& Gambler pada tahun 1999. Pada presentasinya, Ashton memperkirakan potensi IoT dengan pernyataan sebagai berikut: "Internet of Things mempunyai potensi untuk mengubah dunia, sebagaimana yang telah dilakukan oleh Internet. Bahkan mungkin potensinya lebih besar".

IoT kedepannya dapat digunakan untuk menghubungkan entitas fisik dan digital, IoT telah menarik perhatian dunia akademis dan industri, hal ini disebabkan oleh konsep yang ditawarkan oleh IoT untuk menghubungkan seluruh benda-benda (things) disekitar kita, baik menggunakan kabel maupun nirkabel ke jaringan Internet dan benda-benda tersebut dapat saling berkomunikasi dengan campur tangan manusia yang minimum. Tujuan dari IoT adalah untuk menciptakan sebuah dunia, dimana benda-benda dapat lebih melayani dan mengerti, kebutuhan manusia, tanpa perlu ada perintah langsung.

\subsection{NodeMCU ESP8266 Versi 3}

NodeMCU merupakan sebuah Open source platform (fondasi program) IoT dan pengembangan kit (alat) yang menggunakan bahasa pemrograman Lua. NodeMCU berfungsi untuk membantu para makers dalam membuat prototype produk IoT dengan menggunakan sketch pada arduino IDE. NodeMCU dikembangkan berdasarkan pada modul ESP8266 yang mengintegrasikan GPIO, PWM, IIC, Wire, dan ADC dalam satu board. Keunikan board ini dilengkapi fitur Wi-Fi dan firmware yang bersifat Open source . Open source hardware artinya skema dan desain perangkat kerasnya dapat disebarluaskan secara bebas tanpa adanya batasan guna keperluan didesain ulang dan dikembangkan lebih lanjut atau diduplikasi(Fayakun Muchlis, Moh. Toifur,2017).

NodeMCU merupakan firmware berbasis pemrograman LUA untuk ESP8266 Wi-Fi SOC. Model pemrograman pada NodeMCU mirip dengan Node.js namun di LUA.Pada pemrograman LUA juga terdapat parameter untuk fungsi callback.Ini seperti asynchronous dan event-driven (Charoenporn, 2016).ESP8266 merupakan modul Wi-Fi yang berfungsi sebagai perangkat tambahan mikrokontroler seperti Arduino agar dapat terhubung langsung dengan Wi-Fi dan membuat koneksi TCP/IP.

ESP8266 merupakan mikrokontroler yang mempunyai fasilitas koneksi Wi-Fi, modul ESP8266 ini mempunyai prosessor dan memory, yang dapat diintegrasikan dengan sensor dan aktuator melalui pin 
GPIO. Modul ini mempunyai fitur seperti mendukung standar IEEE $802.11 \mathrm{~b} / \mathrm{g} / \mathrm{n}$, bisa digunakan untuk Wi-Fi direct (P2P), AccesPoint soft-AP, mempunyai RAM 81 Mb dan Flash memory 1Mb, kecepatan hingga $160 \mathrm{MHz}$, serta daya keluaran sebesar $19.5 \mathrm{dBm}$.Modul ini membutuhkan daya sekitar 3.3v dengan memiliki tiga mode Wi-Fi yaitu Station, AccessPoint dan Both (Keduanya). Firmwaredefault yang digunakan oleh perangkat ini menggunakan ATCommand, selain itu ada beberapa FirmwareSDK yang digunakan oleh perangkat ini berbasis opensource yang diantaranya adalah sebagai berikut:

1. NodeMCU dengan menggunakan basicprogrammingLUA

2. MicroPython dengan menggunakan basicprogramming python

3. AT Command dengan menggunakan perintah-perintah AT command

Untuk pemrogramannya sendiri kita bisa menggunakan ESPlorer untuk Firmware berbasis NodeMCU dan menggunakan putty sebagai terminal control untuk AT Command. Adapun tampilan dari mikrokontrolerNodeMCU dapat dilihat pada gambar.

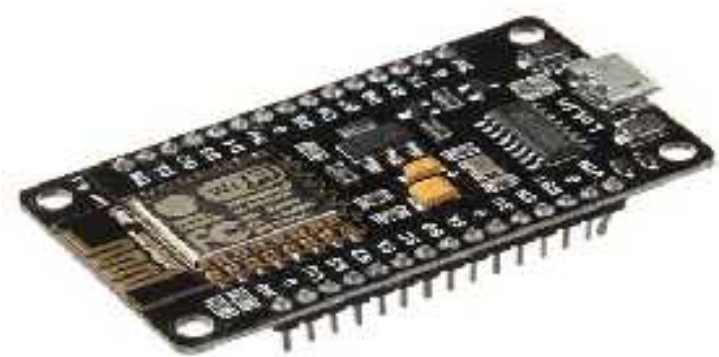

Gambar 2.Mikrokontroler NodeMCU Versi 3

\subsection{Arduino IDE}

Mengenai arduino yang telah diluncurkan dalam situs arduino, yang sampai saat posting ini telah memiliki versi 1.0.1. Arduino sebenarnya adalah perangkat lunak IDE (Integrated Development Environment ). Sebuah perangkat lunak yang memudahkan kita mengembangkan aplikasi mikrokontroler mulai dari menuliskan source program, kompilasi, upload hasil kompilasi, dan uji coba secara terminal serial. Namun sampai saat ini arduino belum mampu men-debug secara simulasi maupun secara perangkat keras, kita tunggu selanjutnya.Arduino ini bisa dijalankan di komputer dengan berbagai macam platform karena didukung atau berbasis Java.Source program yang kita buat untuk aplikasi mikrokontroler adalah bahasa $\mathrm{C} / \mathrm{C}++$ dan dapat digabungkan dengan assembly.Penyusun menggunakan arduino berbasis mikrokontroler NodeMCU dilingkungan jenis ESP8266.

\subsection{Arduino IDE}

Mengenai arduino yang telah diluncurkan dalam situs arduino, yang sampai saat posting ini telah memiliki versi 1.0.1. Arduino sebenarnya adalah perangkat lunak IDE (Integrated Development Environment ). Sebuah perangkat lunak yang memudahkan kita mengembangkan aplikasi mikrokontroler mulai dari menuliskan source program, kompilasi, upload hasil kompilasi, dan uji coba secara terminal serial. Namun sampai saat ini arduino belum mampu men-debug secara simulasi maupun secara perangkat keras, kita tunggu selanjutnya.Arduino ini bisa dijalankan di komputer dengan berbagai macam platform karena didukung atau berbasis Java.Source program yang kita buat untuk aplikasi mikrokontroler adalah bahasa $\mathrm{C} / \mathrm{C}++$ dan dapat digabungkan dengan assembly.Penyusun menggunakan arduino berbasis mikrokontroler NodeMCU dilingkungan jenis ESP8266.

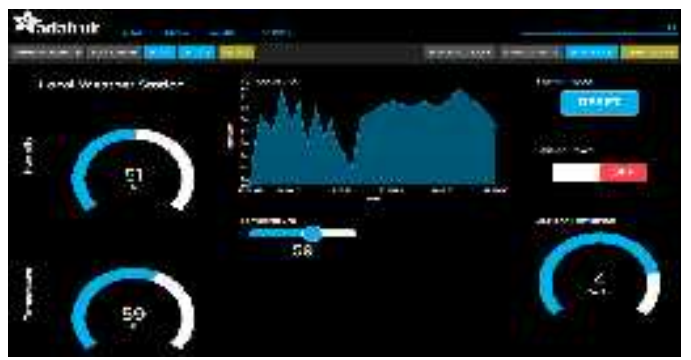

Gambar 3.Dashboard io adfruit 


\subsection{MQTT Dash}

Mqtt Dash adalah Aplikasi dengan sistem operasi open source pada platformiOS dan Android untuk mengontrol beberapa mikrokontroler NodeMCU, Arduino, Raspberry Pi dan sejenisnya melalui Internet.Ini adalah dashboard digital dimana dapat membangun antar muka grafis untuk proyek hanya dengan membuat switch/button yang akan dihubungkan dengan dashboard ioAdafruit. Mqtt Dash ini mendukung perangkat keras pilihan. Apakah NodeMCU atau Arduino terhubung ke Internet melalui Wi-Fi, Ethernet, Mqtt Dash akan membuat useronline dan siap untuk Internet Of Your Things.

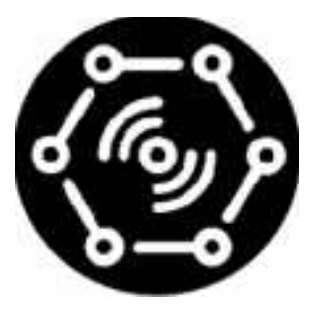

Gambar 4.Logo MQTT Dash

\section{ANALISA DAN PERANCANGAN}

\subsection{Analisa Sistem}

Analisa sistem merupakan tahap mengidentifikasi kebutuhan apa yang harus dipenuhi dalam pembuatan kontrol peralatan elektronik berbasis IoT. Adapun dalam pembuatan laporan ini penulis membagi analisa sistem ke dalam beberapa tahapan yaitu :

1. Analisa Masalah

2. Analisa Kebutuhan Perangkat Keras

3. Analisa Kebutuhan Perangkat Lunak

\subsubsection{Analisa Masalah}

Permasalahan utama yaitu kontrol peralatan elektronik yang dilakukan masih harus manual dengan menekan saklar atau steker lampu. Penelitian ini menganalisa unjuk kerja sistem Aplikasi sederhana web server menggunakan protokol MQTT untuk smart home. Perangkat keras (Hardware) yang digunakan dalam penelitian ini yaitu modul ESP8266, modul ESP8266 merupakan pengendali utama pada sistem smart home, Modul ini berfungsi sebagai webserver, pengendali relay dan client.

\subsubsection{Analisa Kebutuhan Perangkat Keras}

Dibawah ini merupakan tabel analisa spesifikasi perangkat keras dari setiap komponen pengontrolan peralatan elektronik yang dibutuhkan. Adapun spesifikasi kebutuhan perangkat lunak yang dibutuhkan dalam pembuatan prototype dan penggunaannya dapat dilihat pada tabel.

Tabel 1. Analisa Kebutuhan Perangkat Keras

\begin{tabular}{|l|l|cl|}
\hline No. & Nama Perangkat Keras & \multicolumn{1}{c|}{ Spesifikasi Perangkat Keras } \\
\hline 1. & NodeMCU Versi 3 & a. & ESP8266 \\
& & b. & Besar RAM 96Kb, instruction RAM 64Kb \\
& & c. & Tegangan input 3.3V \\
& & d. & Jaringan wifi pada IEEE $802.11 \mathrm{~b} / \mathrm{g} / \mathrm{n}$ \\
& & e. & 10 -bit Adc \\
& & f. & Frekuensi $2.4 \mathrm{GHz}-22.5 \mathrm{GHz}$ \\
\hline 2. & Relay Modul Channel & a. & Input relay $5 \mathrm{v}$ DC \\
& & b. & Maksimum load 250VAC/10A 30VDC/10A \\
& & c. & Memiliki LED Indikator \\
& & d. & Output keluaran 4 channel maksimal $10 \mathrm{~A}$ \\
& & e. & Output memiliki 3 pin terminal block \\
\hline
\end{tabular}

Perancangan Dan Implementasi Prototype Kontrol Peralatan Elektronik Berbasis Internet Of Things MenggunakanNodemcu-( Kusnadi, Petrus Sokibi, Fahrul Ilhami ) 
3.1.3. Analisa Kebutuhan Perangkat Lunak

Tabel 2. Analisa Kebutuhan Perangkat Keras

\begin{tabular}{|c|c|c|}
\hline No. & Jenis Perangkat Lunak & Deskripsi Perangkat Lunak \\
\hline 1. & Sitem Operasi Komputer & Microsoft Windows 8.164 bit \\
\hline 2. & Sistem Operasi Smartphone & Android Versi 7.0 (Nougat) \\
\hline 3. & Aplikasi Editor & $\begin{array}{ll}\text { a. } & \text { Arduino IDE } \\
\text { b. } & \text { Fritzing } \\
\text { c. } & \text { MQTT Dash }\end{array}$ \\
\hline \multicolumn{3}{|c|}{ System MinimumRequirements } \\
\hline & Perangkat Lunak & Deskripsi Perangkat Lunak \\
\hline Sist & m Operasi Komputer & Microsoft Windows 7 32Bit \\
\hline Sist & m Operasi Smartphone & Android Versi 4.4 (Jelly bean) \\
\hline
\end{tabular}

\subsection{Perancangan Sistem Pengontrolan Peralatan Elektronik}

\subsubsection{Diagram Blok Cara Kerja Sistem}

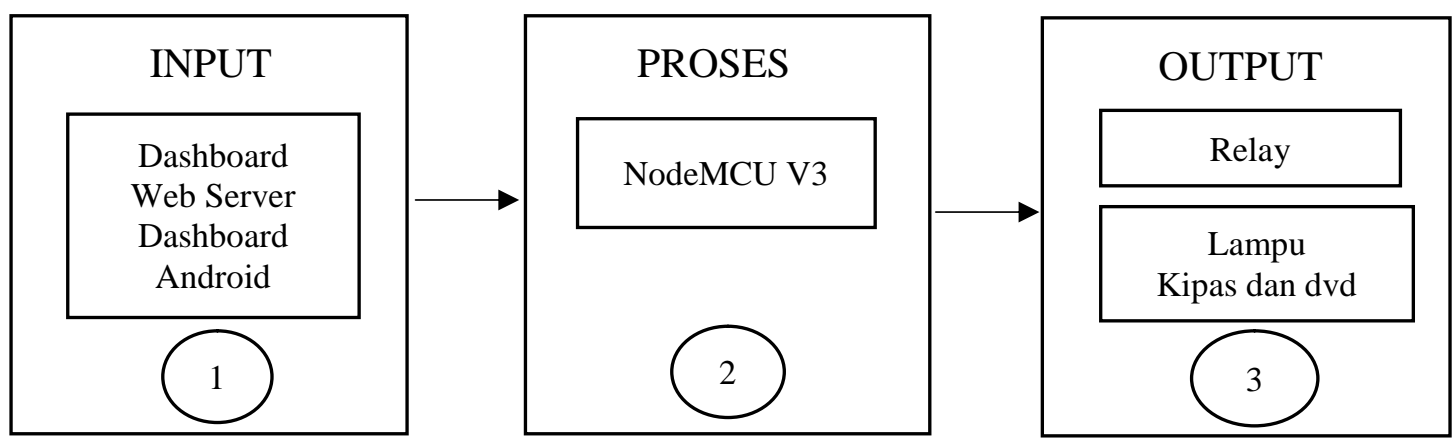

Gambar 5.Diagram Blok Cara Keria Sistem

\subsubsection{Perancangan Skematik Hardware}

Dalam pembuatan bentuk rangkaian sistem pengontrolan peralatan elektronik berbasis IoT setiap komponen memerlukan software fritzing. Software fritzing berfungsi untuk merancang hardware yang dibutuhkan yang sudah tersedia dengan library parts nya masing-masing.

\subsubsection{Interkoneksi Perangkat Keras}

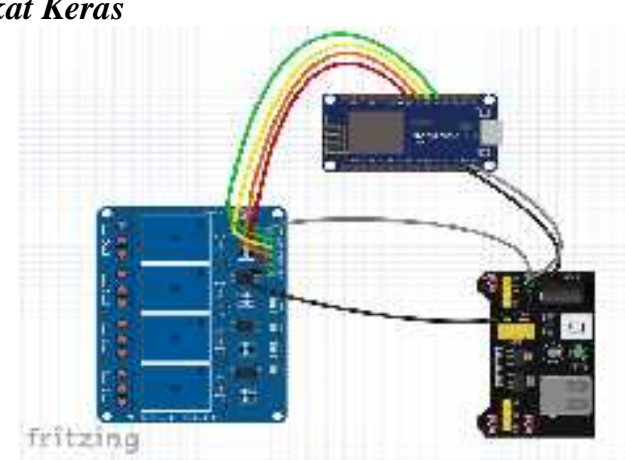

Gambar 6.Interkoneksi Perangkat Keras

Adapun skematik dari interkoneksi perangkat keras pengontrol peralatan elektronik berbasis IoT dapat dilihat pada gambar dibawah ini. 


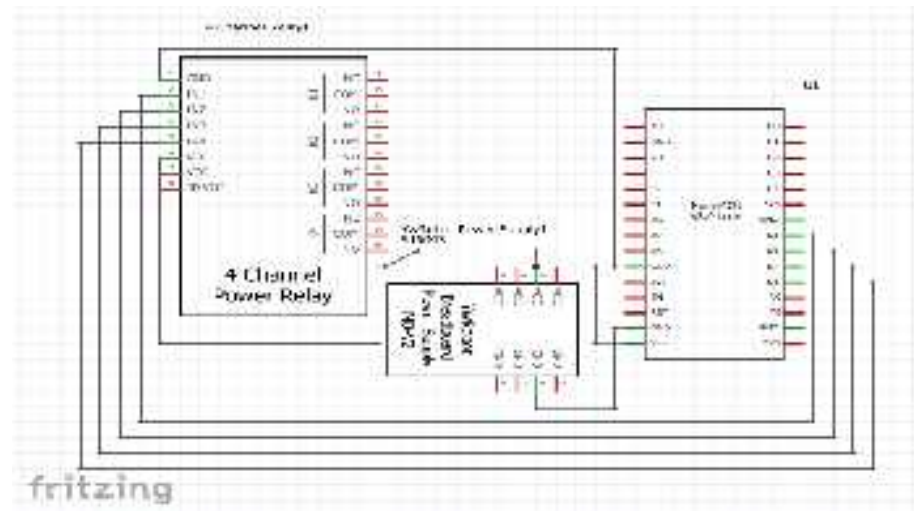

Gambar 7.Skematik perangkat keras pada sistem

\subsection{Perancangan Sistem}

\subsubsection{Diagram Blok Sistem Kontrol Peralatan Elektronik}

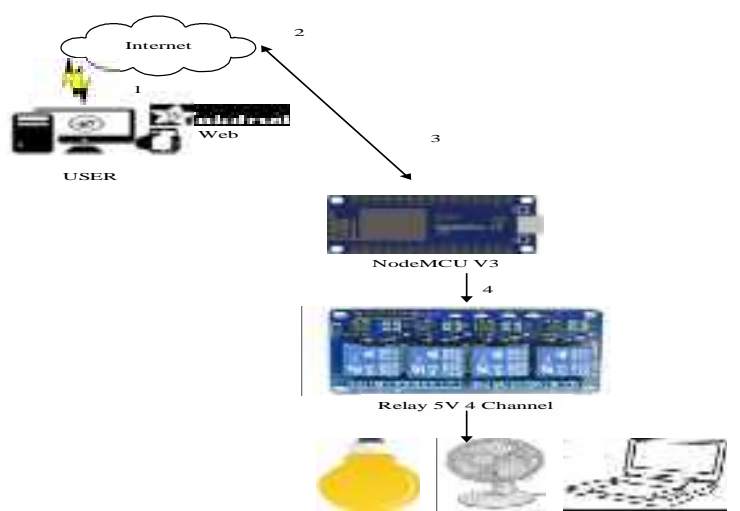

Gambar 8.Diagram Blok Sistem Kontrol Peralatan Elektronik

\subsubsection{Flowchart Cara Kerja Sistem}

Berdasarkan dari perancangan sistem kontrol peralatan elektronik berbasis IoT di atas, maka dibuatlah rancangan sistem. Dalam merancang suatu sistem penulis terlebih dahulu membuat flowchart sebagai panduan untuk membuat sistem.

\subsubsection{Flowchart Sistem yang Sedang Berjalan}

Untuk menganalisa sistem dalam kontrol peralatan elektronik yang sedang berjalan berikut ini flowchart prosedur yang berjalan pada saat ini :

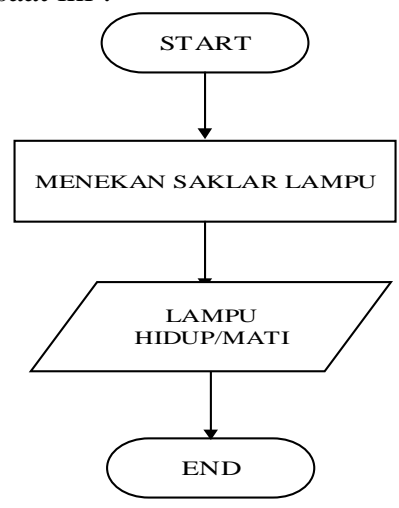

Gambar 9.Flowchart Sistem yang Berjalan 


\subsubsection{Flowchart Sistem Konfigurasi pada Layanan}

\section{Menggunakan Web Server IoAdfruit.com}

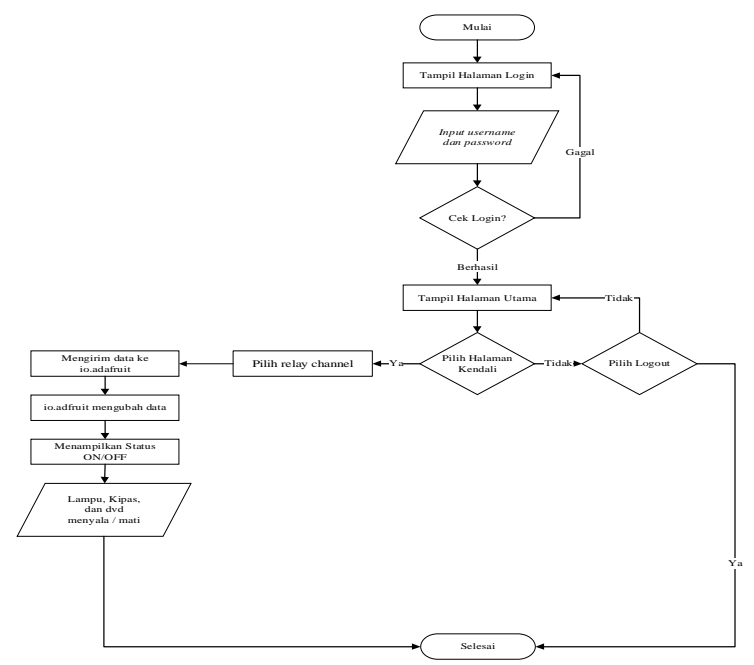

Gambar 10.Flowchart Sistem konfigurasi dengan IOadafruit

\section{Menggunakan Aplikasi Android MQTT Dash}

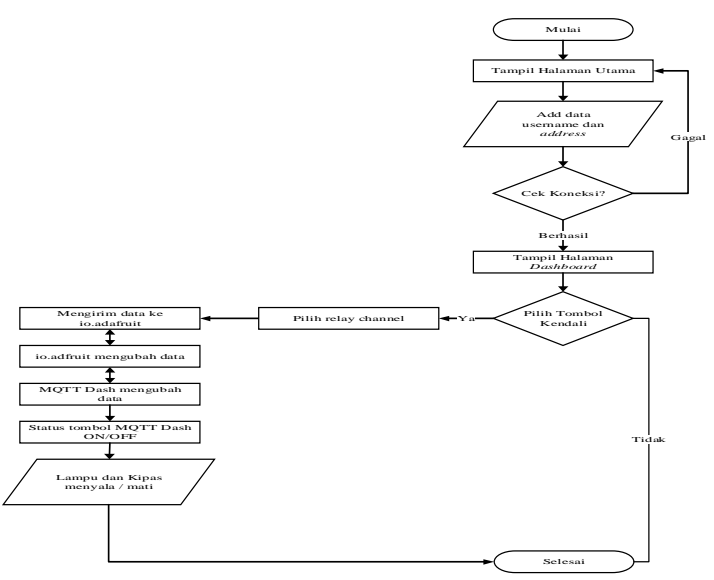

Gambar 11.Flowchart Sistem konfigurasi dengan Aplikasi MQTT Dash

\section{IMPLEMENTASI DAN PENGUJIAN SISTEM}

\subsection{Implementasi}

Setelah dibuatnya analisa dan perancangan sistem pada pembahasan sebelumnya, pada pembahasan kali ini penulis melakukan tahap implementasi meliputi persiapan perangkat NodeMCU beserta modul - modul lainnya, langkah instalasi arduino ide, instalasi ESP8266 pada arduino ide, menambahkan library pada arduino ide, membuat pengontrolan web adafruit dan mqqt dash pada android, dan penulisan kode program serta mengujinya dengan whitebox testing.

\subsection{Pengujian Alat}

Sebelumnya tahap persiapan perangkat sampai implementasi pada perangkat lunak sudah digunakan.Selanjutnya, perangkat yang sudah dibangun harus masuk ke pungujian alat apakah alat atau sistem berjalan sesuai dengan perancangan atau tidak. Dalam implementasi ini penulis melakukan pengujian sebagai berikut: 


\subsubsection{Pengujian Modul Relay Channel}

Relay channel merupakan komponen listrik yang bekerja berdasarkan prinsip induksi medan elektromagnetis. Jika sebuah penghantar dialiri oleh arus listrik, maka di sekitar penghantar tersebut timbul medan magnet. Medan magnet yang dihasilkan oleh arus listrik tersebut selanjutnya diinduksikan ke logam ferromagnetis. Dengan kata lain jika aliran lsitrik berada pada kondisi Normally Close kontak yang secara default terhubung dengan kontak sumber (kontak inti, C) ketika posisi OFF. Namun ketika pada kondisi NO Contact, NO singkatan dari Normally Open. Kontak yang akan terhubung dengan kontak sumber (kontak inti, C) ketika posisi ON.

\subsubsection{Pengujian Sistem dengan Web Server IoAdafruit dan MQTT Dash}

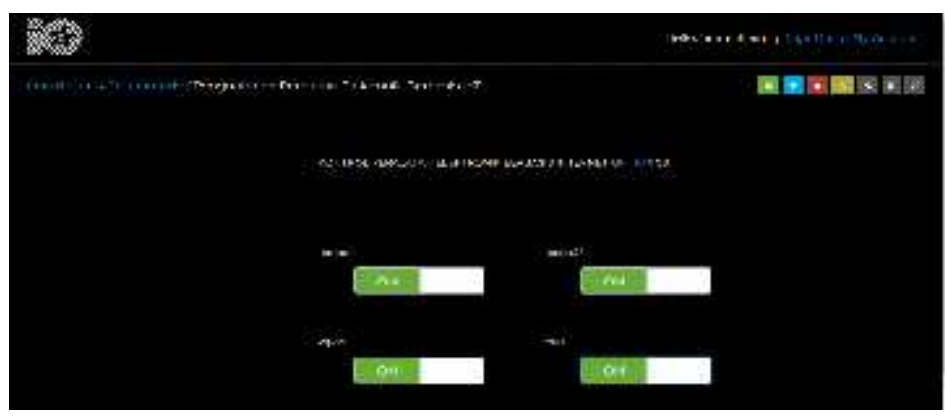

Gambar 12.Pengujian Sistem dengan Web server adafruit dibawah ini:

Sedangkan pengujian sistem dengan menggunakan aplikasi Mqtt dash dapat dilihat pada gambar

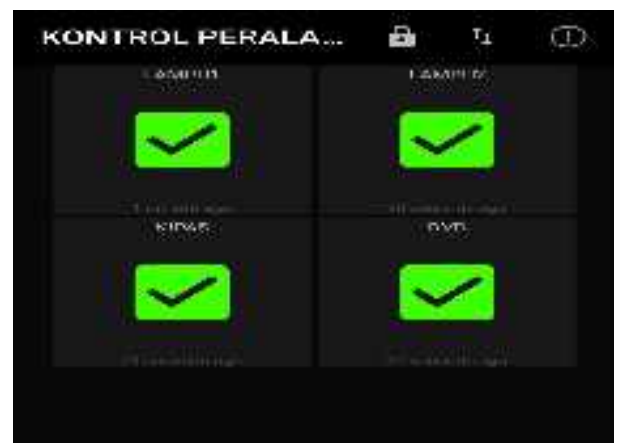

Gambar 13.Pengujian Sistem dengan MQTT Dash

Pada pengujian sistem dengan web server adafruit dan mqtt dash semua button dapat berjalan dengan perintah yang semestinya dilakukan dari input tiap perangkat yang output-nya pada perangkat elektronik.

Tabel 3.Pengujian setiap fungsi button peralatan elektronik

\begin{tabular}{|c|c|c|c|c|}
\hline Relay 1 & Relay 2 & Relay 3 & Relay 4 & Status Relay \\
\hline ON & - & - & - & Menyala \\
\hline- & ON & - & - & Menyala \\
\hline- & - & ON & ON & Menyala \\
\hline- & - & - & - & Menyala \\
\hline OFF & - & - & - & Mati \\
\hline- & OFF & - & - & Mati \\
\hline- & - & OFF & - & Mati \\
\hline- & - & - & OFF & Mati \\
\hline
\end{tabular}




\subsubsection{Desain Rancangan}

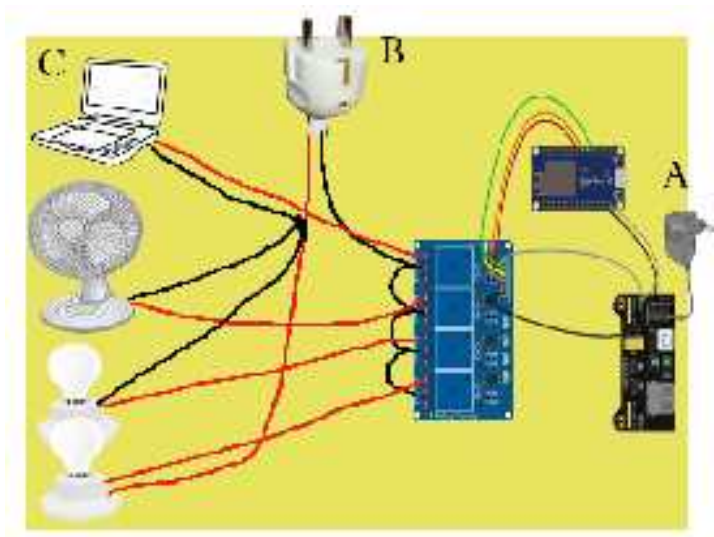

Gambar 14. Inisialisasi Desain rancangan

\subsubsection{Pengujian White Box Sistem}

\section{Flow Graph}

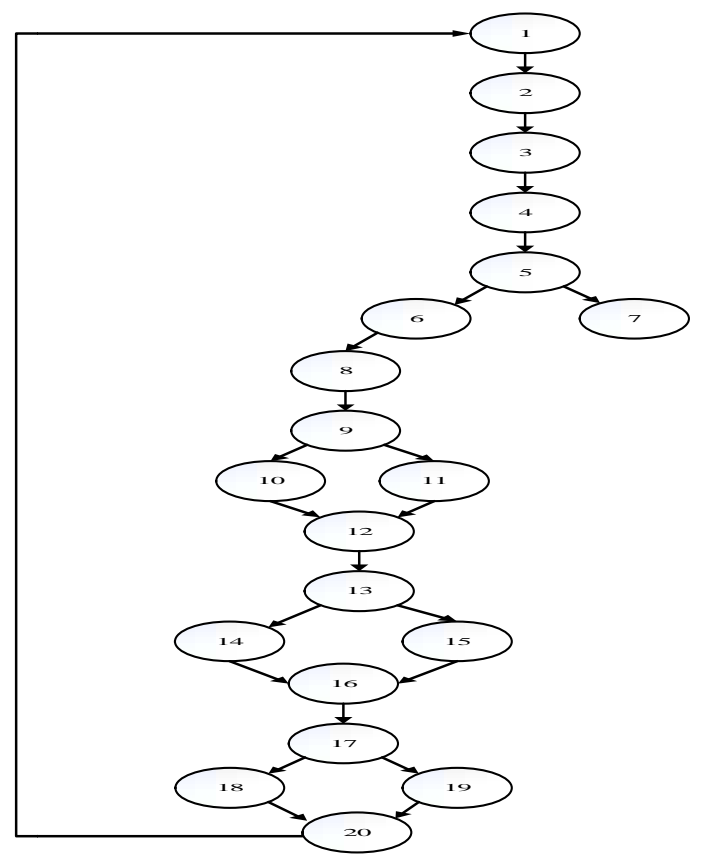

Perhitungan White box :

1. Region $=0$

2. Cyclomatic Complexity :

a. $\quad \mathrm{V}(\mathrm{G})=$ Edge $($ jumlah busur $)-$ Node $($ Jumlah simpul $)+2$

$\mathrm{V}(\mathrm{G})=20-22+2$

$\mathrm{V}(\mathrm{G})=0$

b. $\quad \mathrm{V}(\mathrm{G})=$ Predicate Node +1

$\mathrm{V}(\mathrm{G})=4+1$

$\mathrm{V}(\mathrm{G})=5$

3. Independen Path $=3$

Path 1 : 1-2-3-4-5-6-8-9-10-12-13-14-16-17-18-20

Path 2 : 1-2-3-4-5-6-7-8-9-11-12-13-15-16-17-19-20

Path 3 : 1-2-3-4-5-6-7

4. Graph Matriks Program 
Berikut ini adalah tabel Graph Matriks pada semua program dalam sistem :

Tabel 4.Graph Matriks pada program

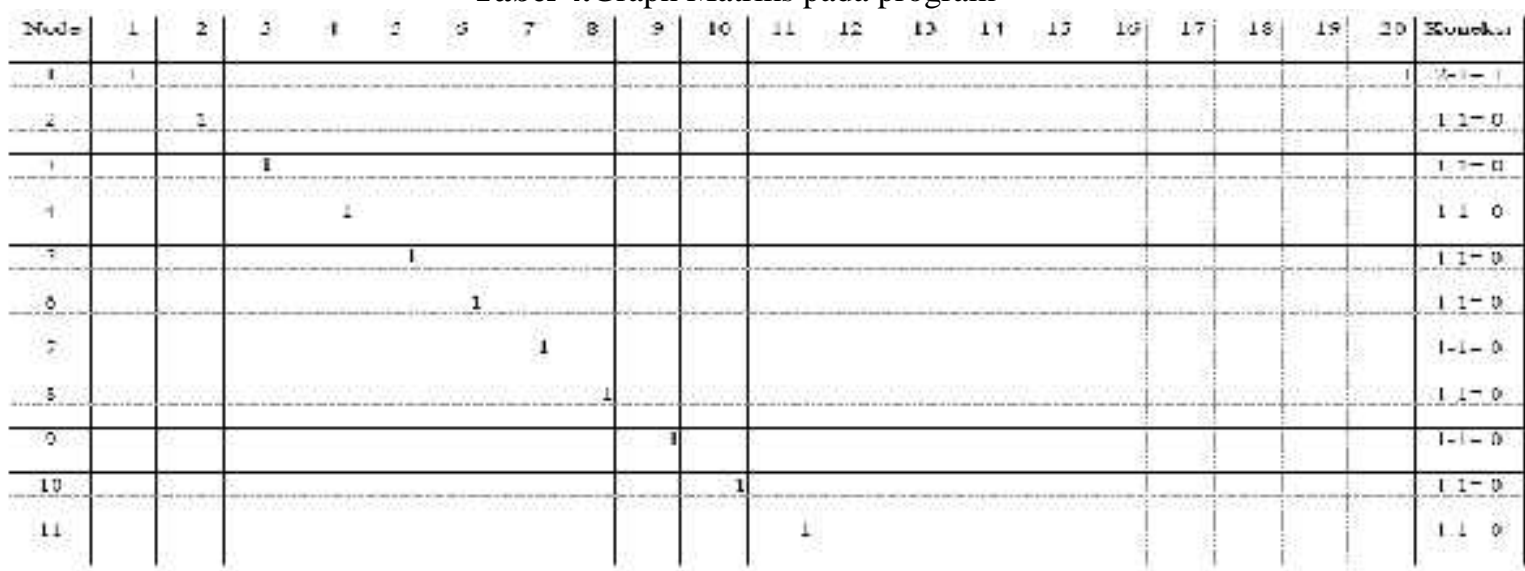

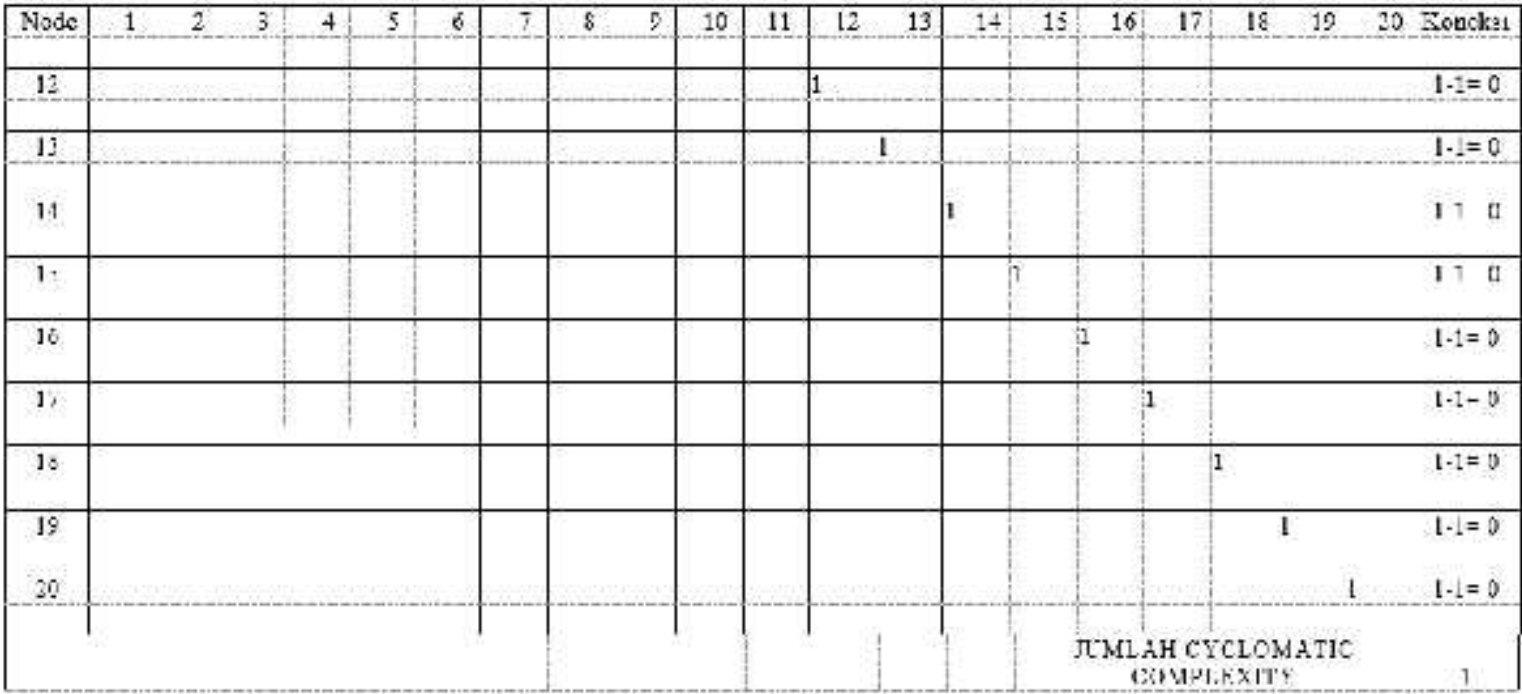

Perhitungan Nilai Cyclomatic Complexity = Nilai Graph Matriks +1

$$
\begin{array}{ll}
= & 1+1 \\
= & 2
\end{array}
$$

\section{KESIMPULAN DAN SARAN}

\subsection{Kesimpulan}

Kesimpulan yang dapat diambil dari pembuatan pengontrolan peralatan elektronik ini adalah :

1. Pembuatan sistem ini berhasil seperti tujuan awal penggunaan yaitu Sistem pengontrolan peralatan elektronik ini menggunakan 2 kendali dalam pengontrolannya. Pengontrolan dapat dilakukan dengan baik melalui web server dan smartphone.

2. Pembuatan prototype peralatan elektronik akan menjalankan fungsinya saling terhubung dengan internet dan dapat diakses dimanapun untuk pengontrolan peralatan elektronik tanpa batasan jarak dengan kendali web server dan smartphone. 
3. Perancangan sistem dibuat menggunakan mikrokontroler NodeMCU sebagai komponen utama dalam model perancangan perangkat yang digunakan yaitu dengan penggunaan Modul Relay channel sebagai pengganti saklar manual.

4. Pengontrolan peralatan elektronik dapat dioperasikan melalui aplikasi Mqtt Dash pada smartphone Android yang sudah disambungkan dengan web server Ioadafruit dengan Modul NodeMCU.

\subsection{Saran}

Adapun saran-saran yang penulis berikan Untuk itulah penulis memberikan beberapa saran dan masukkan agar kedepannya alat ini bisa lebih baik lagi pada implementasinya, diantaranya:

1. Pengendalian sistem pengontrolan peralatan elektronik masih dilakukan secara manual dan belum tersedia pengendalian real time clock dengan modul RTC.

2. Peneltian sebaiknya dilakukan pengembangan pengontrolan peralatan elektronik masih menggunakan aplikasi smartphone yang dibuat sendiri.

3. Penggunaan modul lain dalam penerapan pengontrolan peralatan elektronik seperti sensor suara untuk menyalakan peralatan elektronik dengan suara.

4. Penggunaan modul lain dalam penerapan pengontrolan peralatan elektronik seperti sensor suara untuk menyalakan peralatan elektronik dengan suara.

\section{REFERENSI}

[1] Abdul Kadir. 2012. Panduan Praktis Mempelajari Aplikasi Mikrokontroler dan Pemrogramannya Menggunakan Arduino. Yogyakarta: Andi.

[2] Arif, dkk. 2016. SENTIKA 2016. Di ambil dari: https://fti.uajy.ac.id/sentika/publikasi/makalah/2016/56.pdf.

[3] Andri, dkk. 2018. Implementasi Autentikasi JSON Web Token (JWT) Sebagai Mekanisme Autentikasi Protokol MQTT Pada Perangkat NodeMCU, Malang.

[4] Ardiansyah, 2016. Sistem monitoring air layak konsumsi berbasis arduino,Fakultas sains dan universitas islam negeri alauddin makassar.

[5] Feriz Pradibya Uditama, Rakhmadhany Primananda, Mahendra Data. 2018. Perancangan Aplikasi Pemantauan Pendaki Gunung Menggunakan Wireless Network Dengan Protokol MQTT

[6] Hudan Abdur Rochman, Rakhmadhany Primananda, Heru Nurwasito. 2017. Sistem Kendali Berbasis Mikrokontroler Menggunakan Protokol MQTT pada Smarthome

[7] HM, Jogiyanto, Prototype, Yogyakarta, 2003.

[8] Riska, Harihanto, Agustin Nurmanina, Studi tentang penggunaan internet oleh pelajar, eJournal Sosiatri-Sosiologi, ISSN 0000-0000, (2013).

[9] Santoso, Iman Hedi, and Kalamullah Ramli. "Internet of Things: Visi, Arah ke Depan, dan Teknologi Kunci.” in Proc. Seminar Nasional Teknologi Informasi dan Komunikasi (SENTIKA), Yogyakarta, 2016.

[10] www.sunupradana.info/pe/2016/10/15/mengenal-Fritzing-dan-expresspcb/ diakses pada 15 Mei 2018.

[11] www.ilmukomputer.org ,2009 diakses pada 6 April 2018. 